\title{
Glatte pornokroppe \\ og \\ alternative åbninger
}

\section{Af Mette Grimstrup}

Pornogenren bliver ofte kritiseret for at fastholde problematiske konsstereotypier. Men bvad sker der, nair genven udfordver sine egne konventioner? De seneste airs forsog pai at lave pornofilm til kvinder viser potentialet for en gentankning af pornogenren.

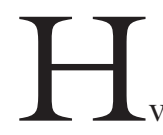

vad er en pornofilm? Som adskillige bekymrede lovgivere op gennem tiderne har erfaret, så er det ikke ganske let at definere hvor grænsen går mellem pornografi og erotik, eller mellem porno og kunst, eller pornofilm og dokudrama. Den amerikanske filmforsker Linda Williams definerer forsøgsvist porno(film) som "the visual (and sometimes aural) representation of living, moving bodies engaged in explicit, usually unfaked, sexual acts with a primary intent of arousing viewers" (Williams, s. 30). Som denne minimumsdefinition antyder, og som de fleste debattører nok kan blive enige om, så handler pornofilm primært om sex. Men hvilken sex?

Denne artikel vil undersøge, hvordan den pornografiske forestilling om eksplicit, “xgte" sex forvaltes i to meget forskellige film, Jessica Nilssons All About Anna (2005) og Emilie Jouvets One Night Stand (2006), som på hver deres måde udfordrer grænserne for pornogenren. Begge film er 
skabt ud fra en kritik af den mandsdominerede pornoindustri, men i modsætning til tidligere tiders kritik af pornografien forsøger de at bruge pornogenrens egne virkemidler til at skabe alternative rammer for repræsentationen af køn og seksualitet. Den feministiske kritik af genren har ofte taget afsæt i en forestilling om, at kvinders seksualitet skulle være mere "erotisk", og at den dermed blev undertrykt af den mandlige, "pornografiske" seksualitet. Og mange kvindepornofilm søger da også at opbygge et mere erotisk univers i form af "blødere" og pænere film. Jeg mener imidlertid denne forestilling kan være med til at fastholde stereotype idéer om kønnene, og at den i sidste ende kan forhindre filmproducenterne $i$ at sætte vigtige spørgsmålstegn ved udformningen af genrens mest grundlæggende element, den eksplicitte, pornografiske representation af "ægte" sex.

Filmene er valgt, fordi de på så forbilledlig vis kan placeres i hver sin ende af det spektrum, jeg ønsker at diskutere i artiklen, mellem erotik og pornografi, og mellem fiktion og dokumentar. All About Anna făr den noget utaknemmelige opgave at fungere som eksempel på den problematiske "erotiske" film, mens jeg bruger One Night Stand til at vise potentialet $\mathrm{i}$ at gentxnke den konventionelle repræsentation af " $æ \mathrm{~g}$ te" sex og af køn og kroppe i det hele taget. Begge film må imidlertid ses som vigtige landvindinger $\mathrm{i}$ den fortsatte udforskning af pornogenrens muligheder for at udfordre vores forestillinger om kønnet.

\section{EN RIGTIG FILM}

I 2005 kom selskabet Innocent Pictures med et nyt bud på pornofilmgenren med filmen All About Anna. I Innocent Pictures lægges vægten på at skabe kvalitetspornofilm, der kan ses af begge køn. Anya Aims, manuskriptforfatteren til All About Anna, fremhæver i et interview, at hun mener et troværdigt plot er afgørende for kvinders indlevelse i pornofilm.: "I believe 
that the female porn-viewers will appreciate a story. A story where every sex scene is incorporated in the drama, where every sex scene drives the drama. I think the question 'why are they having sex now?' is very important to the female spectator."

Innocent Pictures har valgt at tolke dette som et udtryk for, at kvinder vil have pornofilm, der ligner "rigtige" film. I modsætning til i de fleste andre pornofilm er det derfor ikke sexscenerne der er i fokus $\mathrm{i}$ All About Anna. Filmen følger en klassisk Hollywoodmodel, hvor vi følger en individuel hovedpersons udvikling og søgen efter kærlighed, og den søger at fremstå realistisk. Den er filmet i autentiske omgivelser - hovedrolleindehaveren Gry Bays lejlighed i København, cafeer i Paris - og skuespillerne er med en enkelt undtagelse ikke pornoskuespillere, men hovedsageligt folk, der er hentet fra mere traditionelle teater- og filmmiljøer. Skuespillet er om ikke helt på højde med niveauet i mainstreamfilm, så dog en tand mere overbevisende end i de fleste pornofilm.

Den realistiske konvention, All About Anna følger, er kendt som Hollywoodstilen eller kontinuitetsstilen. Det er den måde at lave film på, som blev udviklet i Hollywood i filmmediets tidlige år, og som nu er blevet så udbredt, at den forekommer "naturlig". Den bygger på tilskuerens indlevelse i fortællingen og identifikation med fortællingens figurer. Stilen kan opfattes som "usynlig”, idet den ikke gør opmærksom på sig selv og på hvordan filmens fiktion er blevet skabt, men tværtimod gør sit yderste for at udviske denne produktion. Filmen "fortæller sig selv", og tilskueren skal ikke spørge ind til fortællingens konstruktion, men leve sig ind i den. ${ }^{2}$ De fleste pornofilm skiller sig imidlertid ud fra denne realistiske stilkonvention. Et helt centralt træk ved pornogenren er tendensen til at bryde fiktionen, at stoppe det "flow", kontinuitetsstilen skaber. Pornoskuespillerne kigger ind i kameraet, fiktionens fortælling er oftest kun højst nødtørftigt skruet sammen, og i mange sexscener droppes den narrative sammenhæng fuldstændigt, så de snarere fremstår som et potpourri af forskellige stillinger opstillet til ære for kameraet, end som en fremadskridende fortælling. Tilskueren nægtes dermed den form for indlevelse, kontinuitetsstilen skaber, og tvinges i stedet til at forholde sig til det konstruktionsarbejde, der er gået forud for fiktionen. ${ }^{3}$

Hvad ønsker genren at opnå ved denne verfremdungseffekt? Disse træk er den umiddelbare grund til, at pornogenren ofte afskrives som et underlødigt produkt. Skuespillet er "dårligt", det overbeviser ikke, og historierne latterliggøres. Holdet bag All About Anna ønsker tydeligvis også at lægge disse træk bag sig, og hele filmen er som nævnt et stort anlagt forsøg på at lave pornofilm på mainstreamfilmens præmisser. Men spørgsmålet er, om ikke filmen derved risikerer at sætte et af genrens mest grundlæggende træk over styr, nemlig følelsen af autenticitet, af at se "rigtig sex" udfolde sig på skærmen.

\section{DET UUNDVÆRLIGE COME-SHOT}

Pornogenrens tendens til at overskride fiktionen kan ses som resultatet af en underliggende logik, der præger genren, nemlig diskursen scientia sexualis. Den amerikanske filmprofessor Linda Williams argumenterer i bogen Hard Core. Power, Pleasure and the "Frenzy of the Visible" (1989) for, at pornogenren kan ses som en del af denne moderne seksualitetsdiskurs. Hun følger her Michel Foucaults beskrivelse af scientia sexualis som en selvforstærkende italesættelse af seksualiteten som en indre sandhed i mennesket. Diskursen medfører en konstant granskende tilgang til det seksuelle, idet der omkring det menneskelige seksualliv opstår en vilje til viden, en dynamik bestående af magt, viden og lyst, hvor den 
institutionaliserede videnskabelige spørgen ind til de seksuelle sandheder ledsages af lystfølelsen ved denne spørgen, og af nydelsen ved at vide sandheden om nydelsen. En dynamik, der ifølge Williams kan genfindes inden for pornogenren.

Historisk set har denne udspørgens magtforhold dog ofte været kønsligt ulige fordelt, og dette er ifølge Williams også tilfældet inden for den pornografiske genre. Pornografi søger således at fremlokke sandheder om den kvindelige nydelse ved at fokusere på den kvindelige krops uvilkårlige “tilståelser” af lyst. Men eftersom denne søgen er præget af sit mandlige udgangspunkt, bliver det ifølge Williams til en $s \varnothing-$ gen efter synlige beviser for kvindekroppens nydelse på den mandlige krops præmisser. Den mandlige krops lyst kan til en vis grad repræsenteres visuelt $\mathrm{i}$ form af mandens erektion og ejakulation, men målt på denne led kommer den kvindelige krop til kort. Hendes orgasme har ikke noget ydre, synligt og umisforståeligt kendetegn, men foregår skjult for kameraets blik. ${ }^{4}$ Pornogenrens "løsning" på dette dilemma blev ifølge Williams det synlige come-shot mandens ejakulation ud over sig selv eller kvinden - som endte med at blive det fælles, samlende symbol for den seksuelle tilfredsstillelse. Kvindens eventuelle orgasme blev dermed, på trods af genrens vilje til viden om den kvindelige lyst, ligegyldig for den pornografiske fortælling. 5

\section{DEN PORNOGRAFISKE AUTENTICITET}

Den pornografiske genres fokus på visuel bevisførelse for den menneskelige lyst, som på det indholdsmæssige plan har ført til en prioritering af det synlige come-shot, har også hvad formen angår fort til en konstant søgen efter autenticitet, efter måder at bevise, at der virkelig er tale om "rigtig sex". Og her har det fotografiske mediums særlige karakter spillet en central rolle. Fascinationen af det pornografiske fotografi bun- der ifølge den danske kunsthistoriker Rune Gade i fotografiets indeksikalitet, dvs. i visheden om, at der er en form for direkte forbindelse mellem de afbildede fænomener og de fotografiske tegn. Gade er derfor enig med Williams i, at den fiktive fortælling får en underordnet rolle i pornogenren. Det fascinerende ved pornofilm er ikke fortællingerne, men visheden om de virkelige kroppes "haven-været-der". Pornogenren får dermed også et andet fokus end almindelige mainstreamfilm.

[Det er] "ikke fremstillingen af en troværdig figur, som tæller, men derimod fremstillingen af et autentisk begær, lokaliseret i en virkelig "haven været der"-krop. Det eneste punkt den fotografiske pornografi tilstræber troværdighed på, er i repræsentationen af begærets autentiske intensitet, nydelsens virkelige tilstedeværelse". (Gade, s 224)

Men hvis pornografiens fascinationskraft bygger på den fotografiske afbildning af autentisk nydelse, så er det højst interessant, at All About Anna netop forsøger at gå i den stik modsatte retning. Her har det været en erklæret bestræbelse for holdet bag filmen, at skuespillerne skulle blive $\mathrm{i}$ rollen, også under sexscenerne. ${ }^{6}$ Den autenticitet, de efterstræber, er altså ikke virkelighedens, men fiktionens. Skal man følge Rune Gades fortolkning af pornografi, har producenterne dermed grundlæggende misforstået pornogenren. Pornofilmenes appel bunder ikke $\mathrm{i}$ fortællingen af en god historie, men i muligheden for at få et glimt af "de spredte spor af en virkelig persons virkelige begær, der tilsyneladende vedvarende bryder frem gennem overfladen af fiktionens "dårlige" udførelse," (Gade, s 224). Dette "virkelige begær" har producenterne af All About Anna opgivet til fordel for de fiktive figurers fiktive begær.

\section{ALL ABOUT ANNAS DILEMMA}

Men spørgsmålet er, om ikke dette giver 
meget god mening i forhold til ønsket om at skabe pornofilm til kvinder. Som Gade også påpeger, så kan dette virkelige begær nemlig ikke afbildes. Nydelsens selvtab har ikke noget fast, visuelt udtryk, men må kodificeres og dermed også narrativiseres. $\mathrm{Og}$ dermed løber vi ind i de føromtalte problemer med at finde et visuelt udtryk for den kvindelige nydelse. Hvad den seksuelle tilfredsstillelse angår, er den mandlige ejakulation som nævnt blevet det fælles, symbolske tegn for begge parter.7 Når Gade taler om "autentisk nydelse", så er det dermed meget muligt, at denne autenticitet højst opleves som nogenlunde troværdig for de mandlige parters vedkommende. Hvis det autentiske begær således i forvejen opleves som fiktivt, er løsningen måske at droppe den utroværdige autenticitet til fordel for en troværdig fiktion. Dette synes langt hen ad vejen at have været intentionen med $A l l$ About Anna. Vi skal ikke tro på skuespilleren Gry Bays nydelse, men på hendes figur, Annas, seksuelle oplevelser.

Filmen rejser dermed et interessant spørgsmål: Er det slet ikke er muligt at afbilde troværdig, "autentisk", kvindelige nydelse? All About Anna erkender tilsyneladende pornogenrens manglende succes med at repræsentere kvinders nydelse visuelt med overbevisende autenticitet, og nøjes i stedet med at satse på mainstreamfilmens fiktion, på tilskuerens indlevelse og "suspension of disbelief”. Filmen har dermed også afstået fra den pornografiske søgen efter "de spredte spor af en virkelig persons virkelige begær" (Gade, s 224). Denne søgen kan da også som tidligere nævnt ses som en del af en kontrollerende scientia sexualis' udspørgen af kvinden, en fremtvingen af kropslige bekendelser af lyst på fallocentriske præmisser. Men er løsningen derfor at afvise muligheden af at repræsentere kvindelig nydelse inden for et pornografisk univers?

All About Anna fremviser på sin vis det dilemma, som Foucault opridser i Viljen til viden. Hvordan indgår man $\mathrm{i}$ en diskurs omkring seksualitet uden blot at videreføre og gentage denne diskurs' historisk betingede mandlige perspektiv? Foucaults provokerende pointe var, at selv tekster med frigørende intention uværgeligt vil indgå i en italesættelse af seksualiteten, og dermed bidrage til en yderligere udvidelse af det kontrollerende og disciplinerende greb om den menneskelige seksualitet. ${ }^{8}$ Fra et feministisk perspektiv er det på den anden side heller ikke muligt blot at afstå fra at tale. Som Linda Williams formulerer det:

"The constant speaking about sex does not necessarily advance the cause of sexual freedom; yet at the same time, feminists can't not speak about sex for the simple reason that, until quite recently, almost all sexual discourse - from the writings of Denis Diderot to hard-core film - has been spoken by men to other men". (Williams, s. 15)

Kvinder er med andre ord nødt til at tale, for ellers gør mænd det for dem.

- All About Anna afstår fra at tale. Filmen viger uden om den fremtvingen af kroppenes tilståelser af lyst, som ellers er pornogenrens mest karakteristiske mekanisme. Den satser på en troværdig fiktion frem for pornogenrens tvivlsomme autenticitet. Med god grund, som tidligere nævnt. Pornogenrens autenticitet har indtil videre været betinget af et fallocentrisk visuelt fokus, som begrænser udgangspunktet i kvindelig nydelse. Men dermed forbliver pornogenrens konventionelle autenticitetsudtryk også u-udfordret. Pornografisk autenticitet forbliver noget, der kun kan udtrykkes i konventionelle, fallocentriske billeder - eller slet ikke.

\section{ANDRE MULIGHEDER}

Men hvad sker der, hvis nu vi insisterer på, at pornofilm til kvinder godt kan handle om autenticitet, om "rigtig sex" og overbe- 
visende lyst, og i steder skruer på forventningerne til, hvordan kønnet fremstilles inden for pornogenren? Den franske DIYpornofilm One Night Stand kan give nogle svar.

Filmen One Night Stand er skabt af instruktøren Emilie Jouvet og er opbygget som seks små kortfilm, hvor hver film omhandler et seksuelt møde mellem to parter. Aktørerne er frivillige amatører, og ifølge filmens hjemmeside har alle deltagerne selv været med til at udarbejde historierne efter deres egne seksuelle fantasier. Hver deltager har også valgt, hvem de ønskede at udleve disse fantasier med, samt hvilke former for beskyttelse, de ønskede at bruge. 9 One Night Stand er en queer, lesbisk og transkønnet pornofilm. Den er altså ikke som All About Anna hovedsageligt rettet mod et formodet kvindeligt og heteroseksuelt publikum, men snarere mod mere queer og lesbisk orienterede tilskuere. Dette giver imidlertid filmen en frihed til at følge nogle andre strategier og dermed også til at løse nogle af de dilemmaer, der viste sig i analysen af All About Anna.

\section{IKKE SÅ MEGET SNAK}

I analysen af All About Anna blev det bemærket, at producenterne havde bestræbt sig på at skabe en sammenhængende handling. En troværdig fiktion, publikum kunne leve sig ind i, i stedet for de utroværdige plots, der ellers ofte kendetegner pornogenren. Her går One Night Stand en anden vej. I stedet for én lang fortælling viser filmen som nævnt seks små kortfilm, og fortællingen i historierne er skåret ned til et absolut minimum. I Love me Tender $F^{*}$ me Hard ser vi f.eks. blot en baggård sent om natten og et par der låser sig ind og begynder at kysse på trappeopgangen, før de når op i lejligheden og falder om på sengen. Rapid Sextoy indledes med en kort, venlig forhandling mellem "køberen" og "sælgeren” før det indkøbte sexlegetøj tages i brug. Tilskuerne skønnes altså ikke at have behov for andet end antydningen af en historie til at skabe den narrative baggrund, sexscenerne udfolder sig på. Spørgsmålet "why are they having sex now?", som producenterne af All About Anna lagde så meget vægt på, ${ }^{10}$ synes altså at kunne besvares med meget fă midler. "Fordi de har lyst," fristes man til at svare, efter at have set de seks kortfilm. For i One Night Stand forekommer det pludselig ikke så svært at fremvise overbevisende kvindelig lyst. Filmen indeholder i sagens natur ingen come-shots (ingen af de deltagende parter er i besiddelse af en biologisk penis); i stedet får vi en kavalkade af kvindelige orgasmer. Fra de næsten uhørlige støn i Pink \& Black Gloves, over en kvindelig ejakulation i Love Me Tender, $F^{*}$ Me Hard, til Camerons ${ }^{11}$ langstrakte, højlydte, nærmest dyriske rallen i den sidste kortfilm Red Fetish Bathroom.

Men hvorfor virker denne lyst så meget mere overbevisende i One Night Stand end den gør i konventionelle pornofilm? Jeg skal her argumentere for, at svaret bl.a. hænger sammen med filmens håndtering af den pornografiske autenticitet, og med de muligheder som opstår, når filmen ikke begrænses af genrens konventionelle forestillinger om kønnet.

\section{AutenticiteT SOM STRATEGI}

One Night Stand er filmet med et mini-dv camera, og kvaliteten af filmen fremstår en smule kornet. Kameraet er håndholdt, det glider jævnligt ud af fokus, og i enkelte af scenerne træder kameraførerens skygge tydeligt frem på billederne. Filmen er med andre ord gået $\mathrm{i}$ en helt anden retning end All About Anna. I stedet for at forsøge at udviske de produktionsmæssige rammer spiller omstændighederne omkring optagelserne af One Night Stand en tydelig rolle i den endelige film. Den verfremdungseffekt, som de produktionsmæssige "kiks" skaber, er her ikke forsøgt undgået, men skaber 
snarere som i konventionelle pornofilm en anden stemme, et "autentisk" lag i filmen, som skinner igennem de nødtørftige, fiktive figurer. Det autentiske udtryk er yderligere forstærket i One Night Stand ved hjælp af det ekstramateriale, der følger med dvd'en, og som også vises ved offentlige fremvisninger af filmen. Her er interviews med de deltagende aktører samt en række fraklip fra optagelserne - hovedsagelig tidspunkter, hvor udstyret driller og scenerne pludselig bliver ufrivilligt morsomme, så deltagerne knækker sammen i grin. I interviewene lægger flere af deltagerne vægt på, at filmen er et vigtigt politisk projekt, en måde skabe et rum for og synliggøre ellers marginaliserede kroppe og seksuelle praksisser. Little erklærer stolt, at hun ønskede at vise sin røv til verden, og flere af de andre deltagere, bl.a. Kael og Ali, understreger vigtigheden af at synliggøre transkønnedes kroppe. Som Kael udtrykte det, var han "pleased to be there with my transsexual body, its physical reality" (Jouvet 2006). Adspurgt giver mange også udtryk for at have nydt deres sexscener og at have følt, de udtrykte deres egen seksualitet. Som Shadow siger: "What I like in sex? It's in the film. If you watched it, you know" (Jouvet 2006

One Night Stand benytter sig dermed af det underliggende, "autentiske" lag som en bevidst strategi. Filmen fortsætter for så vidt scientia sexualis' diskursive fremtvingen af bekendelser, men den overtager og udvikler også denne bekendelse til et redskab i kvindernes egne hænder. Ved selv at styre den mekanisme, der hidtil hovedsageligt har fastholdt kvindekroppen som objekt for kameraets undersøgende, mandlige gaze, ind $\mathrm{i}$ andre rammer, xndrer mekanismen karakter. Det krav om synlighed, der gennem pornogenrens historie har været styrende for kameraets udforskning af den kvindelige krop, vendes nu mod genren selv som et krav om retten til at blive set. Et krav om synlighed, også for andre slags kroppe og andre dele af kroppen.

\section{DEN PORNOGRAFISKE KROP}

One Night Stand er som nævnt en queer, lesbisk og transkønnet pornofilm. Man kunne derfor indvende at det ikke giver mening at analysere den i sammenhæn med ellers overvejende heteroseksuelt vinklede pornofilm. Hvis fremstillingen af den mandlige ejakulation f.eks. hidtil har fremstået som problematisk, kan det synes kontraproduktivt at ville hente "løsninger" i en film, der ikke indeholder et eneste biologisk mandligt kønsorgan. Men man kunne imidlertid også vælge at se filmen selv som et argument imod denne opdeling i mandligt og kvindeligt, hetero og homo. Og dermed som et argument for filmens anvendelighed $\mathrm{i}$ andre kontekster ud over filmens egen. Jeg vil foreslå, at One Night Stand kan ses ikke blot som et lesbisk alternativ til mainstream-pornogenren, men som et bud på en radikal ændring af kønsfremstillingen i pornofilm, idet filmen xndrer på definitionen af, hvad der tæller som seksuelle handlinger, og dermed også på definitionen af den kønnede krop. En af de mest iøjnefaldende forskelle på One Night Stand og konventionelle pornofilm er netop kroppenes udseende.

Som noget stort set unikt for genren har pornofilm en egen, letgenkendelig "genrekrop": Slank og veltrænet, med glatbarberet eller trimmet kønsbehåring, og for kvindernes vedkommende de store og strittende bryster, som nærmest er blevet genrens kendetegn. ${ }^{12}$ Endvidere er pornofilm stort set den eneste genre, hvor også kroppenes kønsorganer fremvises og får en central rolle. Disse seksualiserede organer er normalt omgxrdet af sociale tabuer, hvilket ifølge sexologen Annie Potts skyldes, at kroppens åbninger fungerer som socialitetens grænse. Disse åbninger, som tillader kroppen at interagere med omverdenen, afslører kroppens sårbarhed og mangel på integritet. De er ifølge Potts derfor også udsat for den strengeste sociokulturelle kontrol. ${ }^{13}$ Denne tabuisering gør sig gældende i forhold til pornofilmgenren dels $\mathrm{i}$ form af en generel 
samfundsmæssig tabuisering af genren, men også dels i form af en nøje regulering af kønsorganernes fremstilling internt $\mathrm{i}$ genren. Kønsorganer og kropsåbninger er omgærdet af konventioner for, hvilke konstellationer de må indgå i, og hvordan de må afbildes. En penis er altid stor og erigeret, den mandlige anus er forbudt område. Kvinders kroppe er glatte og hårløse, og brysterne er store og faste. Pornofilmens "genrekrop" er typisk kendetegnet ved at være usædvanligt fast, glat og veldefineret. Og netop denne glatte, pumpede pornokrop med overdimensionerede kønsorganer kan ses som genrens forsøg på at fastholde forestillingen om kroppens integritet og kønnets faste forankring. En forestilling, genren netop må arbejde så meget desto mere for at opretholde, fordi den konstant kredser om kroppens ustabile grænseområder.

Kroppene i One Night Stand skiller sig ud ved at være mere "almindelige". Skønt stort set alle medvirkende må betegnes som forholdsvis kønne, er det ikke modelkroppe vi ser, men kroppe med buler og deller, små eller hængende bryster, piercinger, ar efter kønsskifteoperationer osv. Jeg vil foreslå, at denne forskel ikke blot skyldes xstetiske præferencer, men også hænger tæt sammen med filmens håndtering af pornogenrens traditionelle kønsfremstilling. Hvor repræsentationen af sex i konventionelle pornofilm som nævnt synes at kræve en "overtydeliggørelse” af kønnene, så afhænger de seksuelle handlinger i One Night Stand ikke af, hvilke køn eller kroppe, deltagerne er udstyrede med, men af hvordan de bruger kroppen. Og heri ligger muligheden for grundlæggende at ændre forestillingerne om, hvad sex, køn og kroppe er for nogle størrelser.

\section{DET FLYDENDE KØN}

Det er en tilsyneladende selvfølgelighed, at kroppens køn konstrueres ud fra kroppens kønsorganer. Men denne selvfølgelighed er bl.a. blevet problematiseret af teoretikeren Judith Butler, idet hun påpeger, at opfattelsen af kroppens køn altid bygger på en diskursiv forforståelse af, hvad "køn" er:

"Not only is the gathering of attributes under the category of sex suspect, but so is the very discrimination of the "features" themselves. That penis, vagina, breasts, and so forth, are named sexual parts is both a restriction of the erogenous body to those parts and a fragmentation of the body as a whole". (Butler 1990, s. 155-156)

Butler advarer imidlertid mod at tro, at et frigørelsesprojekt derfor må tage udgangspunkt i en "uskyldig” fysisk krop, i kroppen som den er før alle disse normative, diskursive processer sætter ind. Kønnet er ifølge Butler en regulatorisk praksis, en produktiv norm, og hun understreger, at "once "sex" is understood in its normativity, the materiality of the body will not be thinkable apart from the materialization of that regulatory norm" (Butler 1993, s. 2). Forandringsmulighederne ligger ifølge Butler snarere i det forhold, at kønnet må forstås som en proces, snarere end som et stabilt faktum. Kønnet skabes ved den konstante gentagelse af den kønnede norm. Men netop det at denne konstante gentagelse er nødvendig, viser, at systemet er ustabilt, at kroppen aldrig helt lever op til de normer, den formodes at virkeliggøre. I gentagelserne ligger derfor også muligheden for "mislykkede" gentagelser, for kropshandlinger som sætter spørgsmålstegn ved den kønnede norm. ${ }^{14}$

Butler ser bl.a. dragperformances som eksempel på en sådan subversiv kropshandling. Andre teoretikere som bl.a. Beatriz Preciado har dog fundet det mere hensigtsmæssigt at fokusere på kønsteknologier frem for på kønsperformances, for mere konkret at kunne analysere produktionen af kønnet. ${ }^{15}$ Dette perspektiv er også brugbart i forhold til One Night Stand, eftersom denne film netop benytter sig af nogle af de 
teknikker, Preciado gennemgår. I sit provokerende kontrasexuelles Manifest foreslår Preciado f.eks. som en konkret, subversiv kropshandling at erotisere dildoen og anus frem for, som nu, penis og vagina. Alle mennesker har, eller kan bringe sig i besiddelse af begge dele (eftersom dildoen forstås meget bredt som "alt hvad der kan benyttes som en dildo"), og udgangspunkterne for lyst og nydelse er således mere demokratisk fordelt. ${ }^{16}$ Det vil føre for vidt her at komme ind på den fulde rækkevidde af Preciados teorier. Men brugbart for denne analyse er hendes forslag til, hvordan man "dildoficerer" forskellige kropsdele, dvs. benytter diverse kropsdele som dildoer. Stort set alt kan bruges - arme, ben, bryster, hovedet, sågar penis. En dildo forstås således ikke som en erstatning for penis, tværtimod - penis bliver en erstatning for dildoen. ${ }^{17}$ Ved på den måde at vende den kropslige symbolik på hovedet forbliver Preciado i princippet inden for den kønsdiskurs, Butler kritiserede for at "fragmentere" og opsplitte kroppen. Men hun forsøger at gøre det til en mere åben og bevægelig diskurs.

Mit bud er, at filmen One Night Stand netop indgår i en sådan undergravende "kontraseksuel" omrokering af kroppens kønnede udtryk. I stedet for bevidstløst at gentage konventionelle kønsforestillinger, bruges pornogenren altså her til at afsøge alternative kønsudtryk. I Pink \& Black Gloves, for eksempel, fokuseres især på hænderne, idet de gummihandsker, kvinderne benytter til beskyttelse, erotiseres. Via hændernes gensidige indsmøring i glidecreme og det senere "meat-shot", hvor hånden har overtaget penis' traditionelle rolle, bliver hånden gjort til et erotisk objekt. I Dogs er det Alis sorte påspændingsdildo, som slikkes, kærtegnes og feticheres som erotisk objekt.

Kroppene i One Night Stand er således bevægelige, foranderlige. De fremstår ikke som glatte og lydefri, men som åbne for forandring og omdefinering. Selv kroppenes køn synes pludselig ikke længere at være så fast forankret. Og ifølge Butler hænger kønnet netop tæt sammen med, hvilke former for nydelse, kroppen tillades at opleve:

"Some parts of the body become conceivable foci of pleasure precisely because they correspond to a normative ideal of a gender-specific body. Pleasures are in some sense determined by the melancholic structure of gender whereby some organs are deadened to pleasure, and others brought to life". (Butler 1990, s. 95-96)

One Night Stand viser kroppe som i højere grad fokuserer på nydelse end på at efterleve traditionelle kønsnormer. Ved at bevæge sig ud over den kønsopfattelse, der ligger til grund for traditionelle pornofilm, bliver One Night Stand i stand til at omdefinere kroppens erotiske zoner, eller med Butlers ord, bringe andre dele af kroppen "til live". Og netop derved bliver det måske muligt at fokusere på den nydelse, der ikke lod sig repræsentere inden for et fallocentrisk visuelt regime.

\section{PORNOGRAFISKE POTENTIALER}

I artiklen her er forestillingen om en mere "romantisk" kvindelig pornografi blevet problematiseret. All About Annas hybridform mellem romantisk komedie og pornofilm blev set som et eksempel på, hvordan forestillingen om kvindens seksualitet som i særlig grad romantisk og plot-orienteret kan føre til kvindepornofilm, som snarere bekræfter end udfordrer de fordomme, filmene ifølge producenterne bliver skabt som et opgør med: Nemlig at kvinder i virkeligheden slet ikke er til pornofilm, forstået som den ukunstlede fremvisning af eksplicit sex.

Mit xrinde er imidlertid ikke at afvise brugen af en mere avanceret rstetisk udformning eller et veldrejet plot til at skabe 
anderledes, udfordrende og knap så traditionelt kønnede pornofilm. Både inden for pornofilmens mere fetich-prægede undergenrer og i nyere, feministiske pornofilmsproduktioner bruges disse xstetiske greb i høj grad til at åbne nye muligheder for genren og ændre tilskuerens forventninger til de kønnede roller. Min pointe er snarere, at der også er noget at hente ved at gå den anden vej.

Man kan se genren som spændt op mellem to poler: På den ene side repræsenterer pornogenren de seksuelle fantasier, det fantastiske "pornutopia", hvor alle altid har lyst og kommer i stride strømme. På den anden side er den også manisk optaget af at indfange "virkeligheden", den autentiske lyst, "rigtig" sex. Heraf genrens forkærlighed for amatørisme og dokumentar-præget kameraføring.

Mange af de forsøg, der har været gjort på at skabe pornofilm til kvinder, har ofte fokuseret mest på at ændre og finpudse genrens mere fiktionsprægede elementer. Man har - absolut relevant for en gentænkning af genren - forsøgt at skabe pornofilm, som lå mere i tråd med kvinders seksuelle fantasier. Men hvad One Night Stand viser, er at der også kan skrues gevaldigt på knapperne i den anden ende af spektret. At dokumentationen af "rigtig" sex ikke nødvendigvis altid vil fungere som pornogenrens rituelle bekræftelse af kønnet og kønsrollerne, men tværtimod kan bruges til at ændre vores grundlæggende opfattelse af, hvad sex er, og dermed også af betydningen af kønnet og kroppen i det hele taget.

\section{Noter}

\section{Se}

http://www.innocentpictures.com/aaa_screenwriter.php

2. Hill (2003), s. 15-17

3. Gade (1997), s. 161

4. Williams (1989), s. 48-59

5. Williams (1989), s. 48-49 
6. Se http://www.innocentpictures.com/aaa_beskrivelse_da.php

7. Gade (1997), s. 216

8. Foucault (1994), s. 22-25

9. Se http://www.onenightstand-lefilm.com/manifesto.html

10. Se

http://www.innocentpictures.com/aaa_screenwriter.php

11. Alle filmens deltagere arbejder under pseudonym. Jeg har undladt anførselstegn af hensyn til læseværdigheden.

12. Det bør naturligvis her bemærkes, at langt fra alle pornofilm følger denne standard, som dog ikke desto mindre er kommet til at repræsentere det typisk pornografiske kropsideal.

13. Potts (2997), s. 177

14. Butler (1990), s. 188-189

15. Preciado (2003), s. 71

16. Ibid., s. 18-19

17. Ibid., s. 59

\section{VÆRKER}

- All About Anna (91 min.) 2005. Instrueret af Jessica Nilsson, Innocent Pictures.

- One Night Stand (100 min.) 2006. Instrueret af Emilie Jouvet, Hysterie Prod.

\section{LITTERATUR}

- Butler, Judith: Gender Trouble (1990): Feminism and the Subversion of Identity. Routledge Classics, New York.

- Butler, Judith: Bodies that Matter: On the Discursive Limits of "Sex" (1993): Routledge, New York. - Conway, Mary T. (1997): "Spectatorship in Lesbian Porn: The Woman's Woman's Film”, Wide Angle 19, nr. 3.

- Diederichsen, Diedrich, André Rottman \& Mirjam Thomann (2006): „Preface“, Texte zur Kunst, nr. 64.

- Foucault, Michel (1994): Viljen til viden. Seksualitetens historie 1. DET lille FORLAG, Frederiksberg.

- Gade, Rune (1997): Staser. Teorier om det fotografiske billedes ontologiske status \& det pornografiske tableau. Passepartout's særskriftserie, Aarhus.

- Grimstrup, Mette (2007): Lysende af lyst.
Forestillinger om køn og autenticitet $i$ pornofilm for kvinder. Københavns Universitet, København.

. Hill, John \& Pamela Church Gibson (red.)

(2003): Film Studies: Critical Approaches. Oxford

University Press, Oxford.

- Potts, Annie (2002): The Science/Fiction of Sex: Feminist Deconstruction and the Vocabularies of

Heterosex. Routledge, New York

- Preciado, Beatriz (2003): kontraxesuelles manifest. b_books, Berlin.

- Segal, Lynne (1994): Straight Sex: The Politics of Pleasure. Virago Press, London.

-Williams, Linda (1989): Hard Core: Power, Pleasure, and the "Frenzy of the Visible". University of California Press, Berkeley and Los Angeles.

\section{SUMMARY}

The article examines whether pornographic movies for women are able to address questions of gender and sexuality in a more reflexive and less phallocentric way than that of traditional pornography. Analyzing the movie All About Anna (2005) I discuss why the producers seem to avoid one of the most $d i$ stinctive features of pornography - the feeling of authenticity, of "real lust" visible on screen. This "real lust" has so far mostly been symbolized via the visible male come shot, and the film producers struggle to find a female equivalent. I argue that the film producers' inability to visualize female lust in an "authentic" setting is caused by their still being constrained by the traditional porn genre's phallocentric gender patterns. Using the French lesbian, queer and transgender pornographic movie One Night Stand (2006) as an example, I argue that by changing the gendered expectations and by consciously deploying the genre's quest for authenticity, this movie solves some of the problems that appear in All About Anna.

Mette Grimstrup, Kommunikationsmedarbejder, PLS - Pædagogstuderendes LandsSammenslutning. 